\title{
The impact of autocracy on ibn Moataz's poem
}

\author{
Ramezani, Robabeh, Ph. D ${ }^{1, a^{*}}$, Asghari Matikalaee, Hosein Ali ${ }^{2, b}$ \\ ${ }^{1}$ Assistant professor, Faculty, Arabic Language and Literature Group, Alameh Tabatabei \\ University, Iran \\ ${ }^{2} \mathrm{PhD}$ student, Arabic Language and Literature Group, Mashhad Ferdowsi University, Iran \\ E-mail address: Ramezani@aut.ac.ir ${ }^{a}$, Asgharimatikolaee@stu.um.ac.ir ${ }^{\text {b }}$
}

\begin{abstract}
Keywords: autocracy, ibn Moataz, poem, psychoanalysis, intertextuality
\end{abstract}
ABSTRACT. It is not an easy task to learn complicated political and social situation of Abbasid history and its impact on the behavior of kingdom and ruling classes.

Prince Abdullah ibn Moataz is a poet and author and one-night king who entered poetry and literature by autocracy spirit. There are issues like description, wine, glory, pray and epics in his poets, his book namely Al-Badie (Niche) and his proses.

$\mathrm{He}$ is a poet born in political strangulation and observed assigning and withdrawing frequent Abbasid rulers by Turk commanders including the murderer of his father. Then, by his mother's ingenuity, he resorted to poetry and literature. He never forgot these bitter memories. However, it was not only influential in his one-day administration, but also it caused his homicide like previous Caliphs.

In present paper, in terms of ibn Moataz's autocratic basis is technically analyzed by his complete poetical works. Also his Shahnameh - type approach on some poetical themes such as description, wine, lyric poem and hunting are decoded.

In terms of high social basis in poetical themes and in ibn Moataz's books, one can learn a right approach on political and social conditions of Abbasid age generally and the atmosphere of Abbasid royal court particularly.

\section{INTRODUCTION}

By the victory of Abu Al-Abbas Safah over Ommiad's in 132 (lunar years), Abbasid's five hundred years administration started. Despite of decentralization, this age was accompanied with many falls and downs. Competition among Arabs, Iranians and Turks over power finally yielded to conquer Baghdad as the capital of Abbasids by Mongolian Holaku Khan in 656 (lunar years). Abdullah ibn Moataz inb Motevakel born in the second century of Abbasids' administration when the heavy shadow of death dominated over Abbasid caliphs. Abdullah had only 40 days that Turk commanders killed his grandfather in Royal tent. They killed his father when he was 8 year-old.

It seems that the experience of living in palace and being far from policy create an ambience for him to spend most his time on literature and to recover his old wounds by prose and poetry. By such insight, then he was recommended for caliphate, he immediately accepted it. Although he had severally avoided it and has said in Moatazed Caliphate History Book (Hussein, 161):

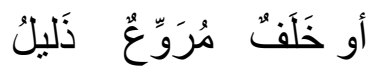

(Every day, a king is killed

$$
\text { وكُلّْ يومِ مَلِكِ مقتولُ }
$$

or is replaced by a timid king)

No the question is that which kinds of poetries associate his autocracy? Can one find his childhood failures in his poems despite of his life in an autocratic life?

The author found no book or paper on the impact of autocracy in Ibn Moataz's poetry. Present paper addresses a brief part of Abbasid age along with poet's life. Then, affecting personality traits on his poetry and poetical subjects affected by his autocratic spirit are investigated. 


\section{THE LIFE OF IBN MOATAZ AND ABBASID HISTORY PROCESS:}

Abu Al-Abbas Safah was the founder of Abbasid administration who killed Ommiad's commanders in 132 (lunar) and recognized Anbar City in Iraq as the capital of Abbasids. The impact of Iranians in this age cannot be ignored. Commanders of army, ministers and governor generals were all Iranians who brought absolute administration policy for Arabian community. They disseminated Iranian social lifestyle especially in how to eat, drink, clothes, palace building, organizing ceremonies among Arabs. Social environment was seen so Arabic due to existence many Iranian, Turk, Seryani, Roman and Barbarian elements. Consequently, free opinion expression was a characteristic of this period. Turks were brought as slaves throughout Islamic and neighboring nations to Baghdad and Motasem Ibn Moataz dreamed to buy them in order foster his army. He assigned them as military commanders. Very soon, Turks got power and it seems Abbasids' caliphs were only their shadows in contrary to many individuals who called them as in shadow government.

In this way, when Motevakel became caliph, he felt their danger more than ever and planned to curb them by deceit. However, he failed. Afterwards, Turks dominated the country and weakened caliph so that they became their slaves. Survival or deposal of caliphs was ordered by them; otherwise they were killed. Under such circumstances, Abdullah Ibn Moataz was born in 247 (lunar) in Samira in capital palace. As mentioned, he had only 40 days that Turks killed Motevakel along with his minister Khaghan. According to Taha Hussein, killing Motevakel was a big evil (Hussein: 152).

His Roman mother led him very soon to education. Abdullah showed his genuine soon so that his father was surprised and coined in the name of Abdullah. Bohtary, Abbasid poet, prayed this child Abdullah:

$$
\text { و تقليده مِن أمرنا ما تقلَّدا (ضيف،326) }
$$$$
\text { وَأبهَجنا ضربُ الدنانير باسمه }
$$

(Coining in the name of Abdullah made us happy

how beautiful imitation of our job (poetry))

Such pleasure was not continued too long and the worst memory was happened for Abdullah when Turk commanders attacked the court to receive their salaries and enforced his father to pay their salaries. Since treasury was empty due to bad management, they attacked his fathered and beat him by mace and imprisoned him in a house till he died. Then, they seized his properties and exiled Abdullah and his mother to Mecca.

Abdullah felt the pain of father homicide and exile and its consequences were not released till the end of his life. He remembers both pains:

$$
\text { وَغُصنِهه ذي الوَرقِي النَّضيرِ }
$$

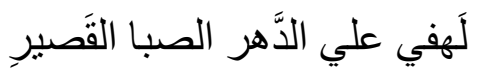

(Alas! To short life of childhood that its tree branch had soft leafs)

$$
\text { وَ مرَح القلوبِ في الصُدورِ }
$$$$
\text { وسُكرِِِو }
$$

(Intoxication and its sin can be forgiven and his inner happiness was from his heart)

$$
\text { في ظِلِّ عيشٍ غافلٍ غَريرِ (ضيف، 326، 326) }
$$

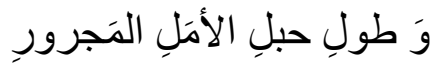

(And the long string of dreams is broken in the shadow of proud negligible happiness)

One year later namely in 256 (lunar) Motamed became caliph. He returned Ibn Moataz and his mother to Samira and his grandmother attempted to educate him. Toward 276 (lunar), he learnt all sciences in Samira and wrote many poetries and books including "Al-Badie", "Al-Javareh and Al Seyd", "Al-Zahr and Al-Riad" and so on. When Motazed became caliph, Ibn Moataz asked to come to Baghdad by parrying caliph: 


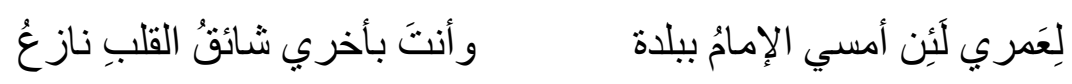

(Oath to my life, if Imam is in one city and you are in another one, you live him)

$$
\text { وَ ما أنا في الدنيا بشيءٍ أَنالُهُ سوي أن أري وجهُ الخليفِة قانعُ (ضيف،331) }
$$

(There is nothing in the world to achieve it and to be convicted except than seen the face of caliph)

Ibn Moataz came to Baghdad. He had better position there. Noteworthy, such social atmosphere in the second Abbasid age was too affected by Iranian culture. Social classes were divided into three parts:

- Superior class including caliphs, ministers, commanders, governor general and their relatives

- Middle class including militarists, employees, traders and distinguished craftsmen

- Lower class including workers, farmers and servants.

Superior class were sank in wealth and they believed that such Divinity gifts over Islamic borders has separated them form remained world.

Ibn Moataz describes “Al-Soraya” Palace as a masterpiece of Motazed's age as:

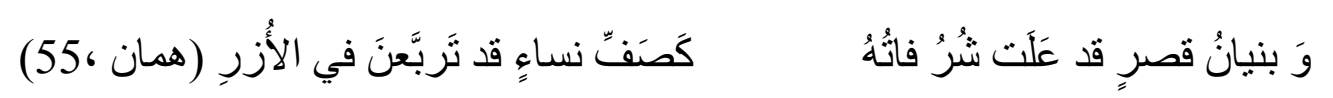

(And the building of a palace with tall walls like women who sitting cross - legged by their skirts)

Over 50 years, Ibn Moataz lived in such autocratic environment. "This is the environment where inspired Ibn Moataz's pure artistic feeling. So he became a good poet." (Hussein, $153)$.

During this age, efforts by Ibn Moataz and his cousins to avoid politics were not only unsuccessful but also entered with unbelievingly into caliphate. A group of Turk commanders matched a fire which involved Ibn Moataz very soon. By giving superiority to 13-year'old "Moghtader" over 52-year-old Ibn Moataz for caliphate position, many commanders and judges ousted Moghtader and promised loyalty to Ibn Moataz. This under ash fire involved Ibn Moataz very soon even for one night since the next day, he as killed and Moghtader took to power. it happened in 296 (lunar).

$$
\text { يعلَمُ ما ضَربةُُ القدرِ (ناظمبان : 51) }
$$

$$
\text { من عاش يوماً أو بعض يومٍ }
$$

(Who lives one or more days would experience the wound of fate)

What mentioned on Ibn Moataz's 52 years life in Samira and Baghdad can be investigated from different aspects. In present paper, we study his personality traits the impacts of autocracy on his poetry by using the psychological achievements and intertextuality.

\section{DESCRIPTION}

A few skillful poets can be found in description since it needs broad imagination, clear language and endless opportunity. All were gathered in Ibn Moataz. He grew in ambience full of material and spiritual gifts.

Preparing the best educational conditions by his grandmother including the best teachers like Mobrad, Salab, Ahmed Ibn Saeed Dameshghi and Balazari and interactions with Bohtary and such scientists as Mohammad Ibn Omran Ibn Zyad and Ahmed Ibn Saleh in literal forums generated a poet who wrote below poetry to appease his instructor Ahmed Ibn Saeed Dameshghi. 


$$
\text { أصبحت يابن سعيدحُزتَ مكرمة }
$$

(Oh Bin Saeed! You are too generous and great that no one could achieve)

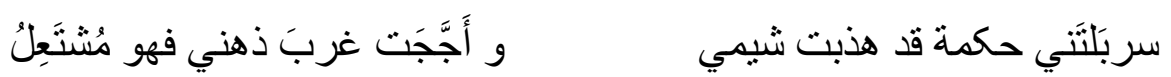

(You taught me wisdom and refined my mindset and grow mu rationality)

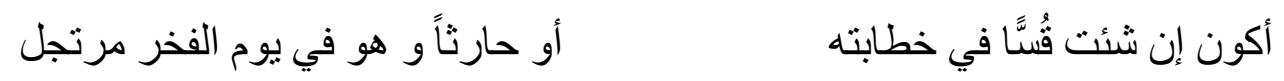

(If I want, I can be Ghas Bin Saedeh ot Hares Bin Hallazeh in speaking who versified spontaneously)

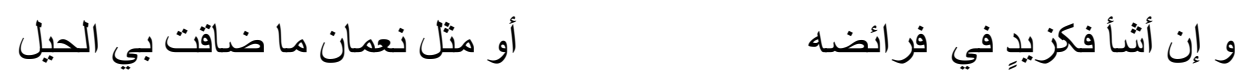

(And if I want, I can Syed Bin Sabet or Namman in wisdom that no ruse could fail him)

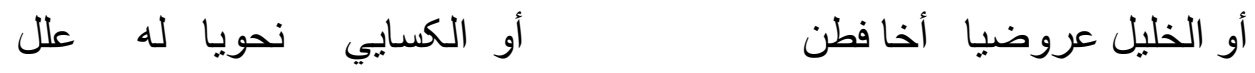

(And if I want, I can become smart Khalil Bin Ahmed or Yall Kasaei who brings convicting reasons)

In his verses, he tells instructor that you made me superior to Ghas in preach; Haris in spontaneous versifying, Khalil in reasoning and Kasaei in syntax. He was aware of such sciences as philosophy, astronomy, music and so on (Zif, 328).

Ibn Moataz saw palaces and gardens in which he hunted and passed nice nights in Iraq beautiful nature with singers and dancers. These are the reasons for wide range of broad imagination and poetry language for a poet. As a result, a poet like Ibn Moataz pays attention to what relates to description like intoxication, pleasure, madness and blessings. His beautiful likening on objects show his care:

$$
\text { حبذّا آذار شهراً }
$$

(Well down to Farvardin in which the lightness is disseminated)

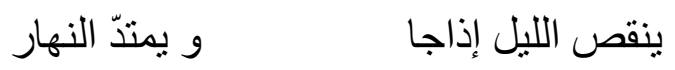

(When it comes, night becomes shorter and day becomes longer)

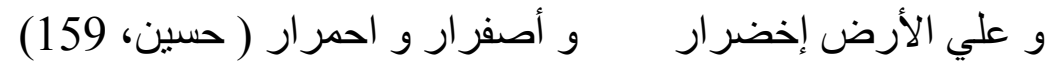

(And there are pleasure and colors on the earth)

In versifying such lyrics, he only aimed at amazing servants and he did not go beyond love between a prince and servants who signed (Islamic Great Encyclopedia, 636).

To the same reason, when Ibn Roomy is asked why your likening is not similar to Ibn Moataz while you are better poet, he says " لا يكلّف الله نفساً الّا وسعها". He describes what is in his home since he is a prince while I am a poet who generates my income through poetry (Zeif, 334).

Ghlghashandi has introduced Ibn Moataz's likening in descriibng jewelries as the ultimate beauty and perfection (Islamic Great Encyclopedia, 637).

$$
\text { أفدي الّّي أهدي إلي مظلّةً }
$$

(Someone who is benevolent to calm and release sadness in my enthusiast heart) 


$$
\text { فكأنّما هي زورق من فضّة قد أو دعو هفي اللجين سلا سلا (الأب شيخو،ج3 ، 166) }
$$

(As if he is like a silver boat in which silver strains are used)

However, Taha Hussein believes that likening Ibn Moataz as a silver boat became heavier by ringlets as sleeping words and imaginations (Hussein, 196, 197).

However, by looking at Kboat likening", one can find that this analysis relates to the environment where Ibn Moataz lives since living in a palace full of gold and silver and watching them every day can bring such imaginations since such imaginations cannot be emerged by poets who have not been in such environments. Bohtary has also mentioned them (Zeif, 295, 296).

Therefore, this likening has a special status in descriibng Ibn Moataz since on the hand, it expresses his awareness of his antecedent poets and, on the other hand, it reveals his prince environment. In Asrar Al-Balagheh, Abdulghaher Jorjani expresses the reason of Ibn Moataz's reputation in likening as: "most Ibn Moataz's likening has made him more reputable since he has used visual senses as the best likening" (Al-Fil, 244).

Therefore, one can say that Ibn Moataz's varied experiences which show his social basis in description and likening are the reasons of his reputation and has taken him to a degree by which he claims: "whenever I say كأنَّ and do not bring likening after that, Allah throws off my teeth."

\section{VENGEANCE}

As mentioned, Ibn Moataz experienced two bitter events in his childhood namely homicide of his father and exile. They highly affected his life so that he always attempted to keep from political life and has no interest to be caliph. However, caliphs namely his cousins prepared the conditions and encouraged him to such life so that he did not remember those accidents. Despite of this, an explicit phenomenon in Ibn Moataz's poetry is to complain the time and people due to his pains by Turks:

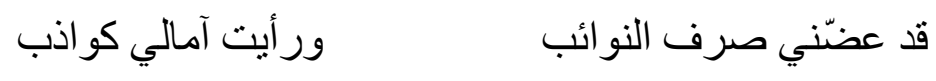

(The teeth of accidents bite me and I found mu wishes false)

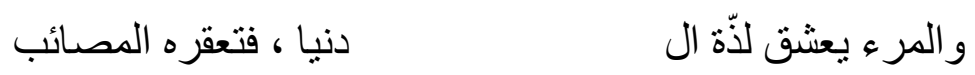

(And human loves global enjoyments but calamities make him bedridden)

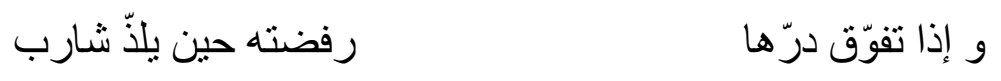

(And when like an animal, the mil is flowed, the drinker of the milk enjoys and the world releases $\operatorname{him} /$ her)

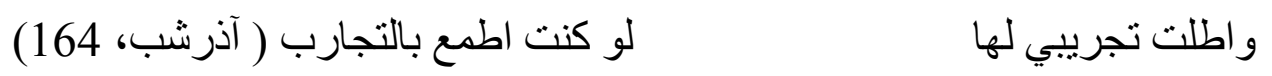

(And for the sake of world and for greediness to experiences, I make my experiences longer)

If we pass this under - ash fire, he believed that Abbasids have the right for administration and believes that they were superior to Ommiad's and explained Marvan Abi Hafseh as:

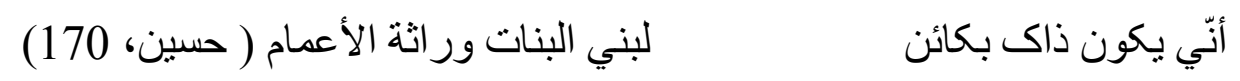

(Where you can see that nephews are inherited from uncles) 
Even, he believed it as Divine fate and said to Alavian:

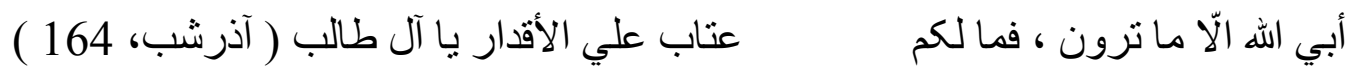

(Divinity does not want. Why you cannot see; Oh Abi Taleb Family! What has happened that you are angry of Divine fate)

Living in palace creates a context for vengeance and although Ibn Moataz attempt to avoid he was not successful since he could observe that they killed his father by hungriness, seized their properties and exiled him and his mother to Mecca. Such events cannot be erased from anybody's memory even though they want to appease. Therefore, they experience what is going to be happened:

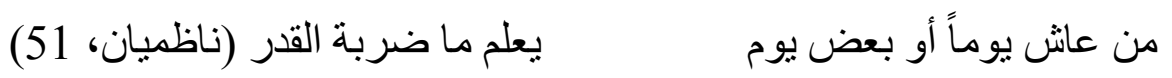

(Who lives one or more days would experience the wound of fate)

Such fire was flamed more when Turks bring to power 13-year-old son of Moktafi (295, lunar). Friends of Ibn Moataz came to him and deposed Moghtader through a coup-d'état and granted administration to Ibn Moataz. He came to power, he told a sentence which shows the depth of his vengeance to his cousins: "now it is the time to reveal right and to shame evil (Islamic Great Encyclopedia, 436). However, the flames of anger and revenge kept him only one night and next morning Moghtader's fans attacked and terminated his one night administration.

He had predicted such fate:

$$
\text { يا شاكي الدهر ! إنّ الدهر ألوان فيه، لصناحبه، بؤس و أحزان }
$$

(Oh plaintiff of time! Know that world is deceitful and brings pains for those who like it)

$$
\text { و في الممات غني المرء يستره ليس مستغنياً ما عاث إنسان ( شيخو، }
$$

(Human needless is hidden by his death and he is not needless when he is alive)

\section{Intoxication}

Intoxication highly relates to poet's social basis. It is a branch of description. Technical invention and innovation in intoxication is achieved when poet has experienced carried environments and times and is too rich. Ibn Moataz was a poet to whom all conditions were prepared. Therefore, no poet in $3^{\text {rd }}$ century has versified on wine as same as Ibn Moataz (Islamic Great Encyclopedia, vol. 4, 636).

"ZAm Al-Sobuh" is an example in which Ibn Moataz renders his extraordinary skills (Taha Hussein, 164). In intoxication, he has used likening such wine vessel, color, taste and odor from morning to night from summer to winter.

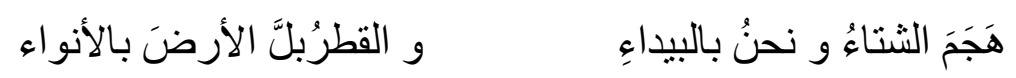

(Winter attacked while we were in desert and rain drops were soaking the earth constantly)

$$
\text { فاشرب علي زهر الرياضِ يشوُبُه زهر الخدود و زهرة الصهباءٍ }
$$

(Drink garden's blossoms which mix redness of faces and wine)

$$
\text { مِن قهوةٍ تتسي الهمومَ و تبعث الشو ق الذي قد ضلَّ في الأحشاءِ }
$$

(From brown wine which causes to forget sad and motivates inner enthusiasm) 


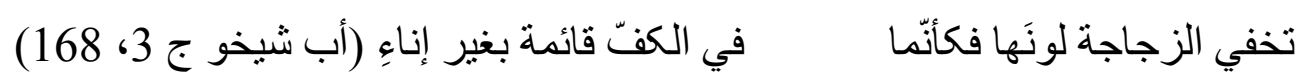

(Wine bottle covers its color as if stands on palm without vessel)

The application of likening in intoxication is obvious while the diversity of likening from nature has caused Ibn Moataz as the poet of nature:

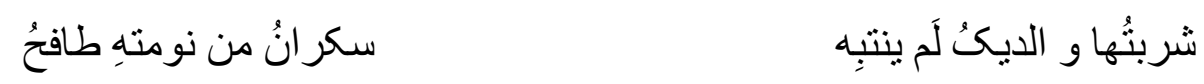

(I drank wine while a drunken man did not wake up cock)

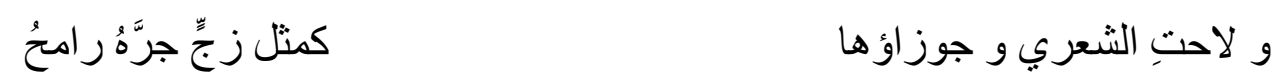

(And a poetry star was revealed in Jawza like the iron under spear that spearman pulls it) In below couplet, he has likened such radiation to wine:

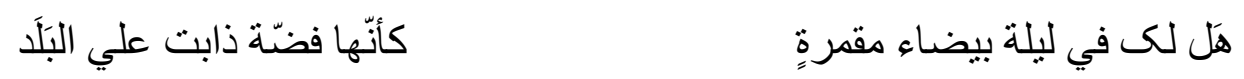

(What has happened to you that in a brilliant night you are like melted silver)

$$
\text { و قهوة كشعاع الشمسِ صافيةٍ }
$$

(Many times, I drank brown wine like sun radiation as is the steps of sun involved its foam)

As Antarat Ibn Shadad honors generosity in drunken and awareness states:

$$
\text { فإذا شربتُ فإنتّي مستهكُّ }
$$

(When I drink wine, I waste mu assets while my is full and deficit-less)

$$
\text { و إذا صحوتُ فما أُقَسِرُ عن ندي و كما عَلمتِ شمائلي وَ تَكَرُّمي ( الزوزني، ص 256) }
$$

(when I awake, I do not forget generosity and my mood is as you know)

In explaining generosity in drunken and awareness states, Ibn Moataz says:

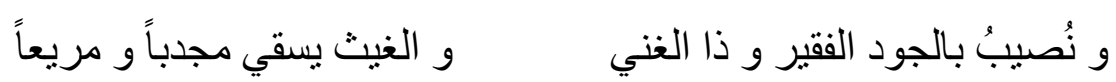

(We grant to rich and poor like raining on fry and wet lands)

Ibn Moataz has spent most his time to drink wine and it has not been limited to a special place or time and it seems that he liked it in order to forget his life calamities the homicide of his father and his age princes:

$$
\text { كأنَّها دمعةٌٌُ من عين مهجور (ضبف 342) }
$$$$
\text { و ليس للهمِّ إلّا شربُ صافيةٍ }
$$

(There is nothing better than pure wine to remove sadness as if wine is like rears from queer's eyes) It should be added that the multiplicity of poems on intoxication shows the beauty of nature and his poetic capability on wine to show his endless love and attachment in wine.

"Zam Al-Sobuh" consists of 120 sentences with varied rhyme which was a technical invention in his time and he versified it as a jest:

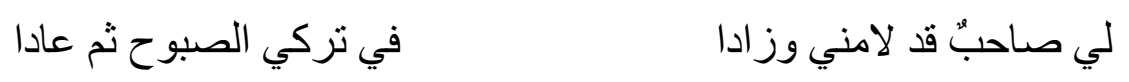

(There is nothing better than pure wine to remove sadness as if wine is like rears from queer's eyes) 


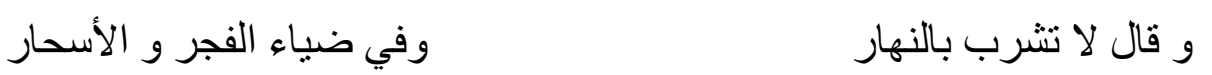

(And told never drink wine in day and early morning)

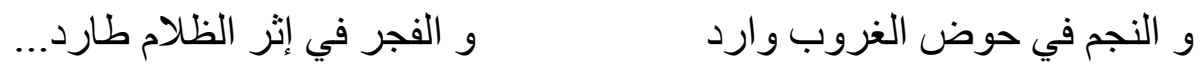

(And the star is entered the pool of dawn and light after darkness)

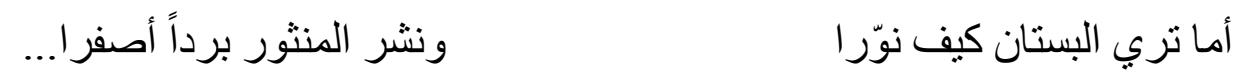

(Didn't you see how the park is lighting and it disseminate well odor of coolness)

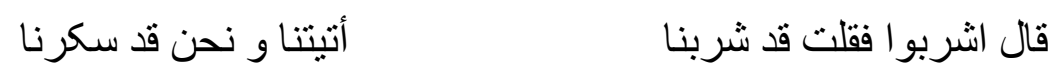

(He told: "drink" and then I told that we would drink and bring wine while we are intoxicated)

$$
\text { و القوم من مستيقظ نشوان }
$$

(And a group of men are awaken and others are sinking in their intoxication and sleep)

Although Ibn Moataz's intoxication is seen by some as a technical initiative (Hussein, 164), others believe that he is impacted by Abunavas' intoxication without any new thing (Abduljalil,

H. M. translated by A. Azarnoosh, Amir Kabir Publications, Tehran, 1994, vol. 2).

\section{GLORY}

Taha Hussein asserts that glory men have the ability to say lie and defend it and to show their small works as big as well as to see the big works of others as small. A little joy would create distance between their life and influence (Hussein, 192).

In the first verses to attract the satisfaction of his instructor Ahmed Ibn Saeed Dameshghi, Ibn Moataz versifies:

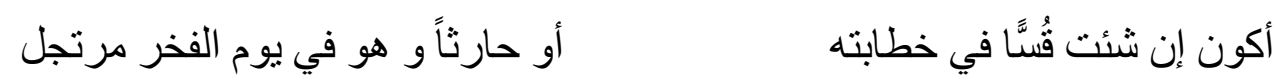

(If I want, I can be Ghas Bin Saedeh ot Hares Bin Hallazeh in speaking who versified spontaneously)

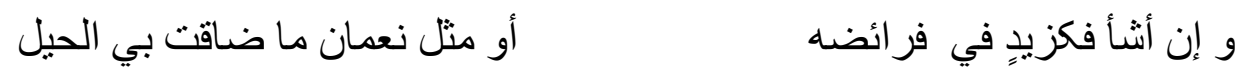

(And if I want, I can Syed Bin Sabet or Namman in wisdom that no ruse could fail him)

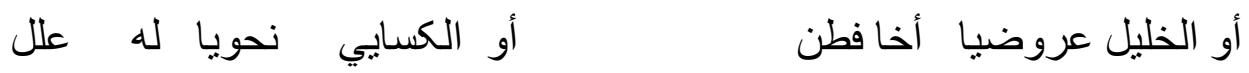

(And if I want, I can become smart Khalil Bin Ahmed or Yall Kasaei who brings convicting reason)

It is too far that a 13-year-old boy could learn different sciences like great men except than in type of exaggeration.

In his elegies in last days of his life, Ibn Moataz did not put aside glory:

$$
\text { حكم الضُّيوفِ بهذا الرَّبع أنفذُ مِن حكم الخلائفِ آبائي علي الأمِ }
$$

(The command of guests in this house is more influential on people than the commands of kings who were may antecedents) 


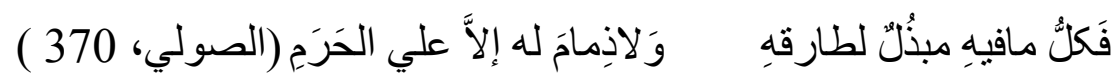

(Thus, anything in this home is gifted to guests who became our guest in night and they do not owe anything except than what is haram)

Even in complaining time coercion, Ibn Moataz is not separated from glory.

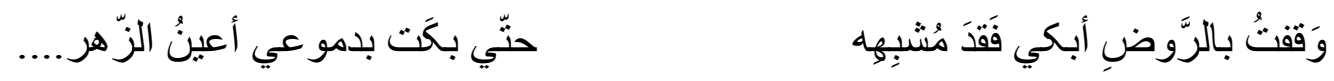

(I stood near the garden and cry for losing garden likening till that blossom eyes were crying by my tears)

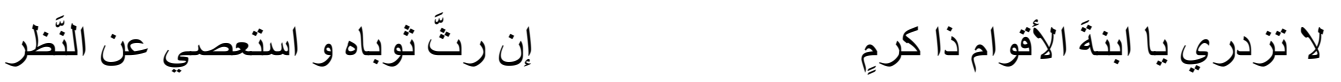

(Oh bitter time, do not see generous human as despised although his clothes are worn out and it is too hard to see him)

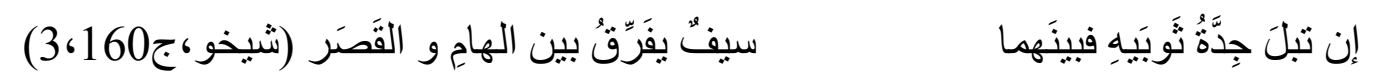

(Although his clothes are worn out recently, his clothes are like a sword which distinguishes throat and neck)

He even prides in descriibng rain and war:

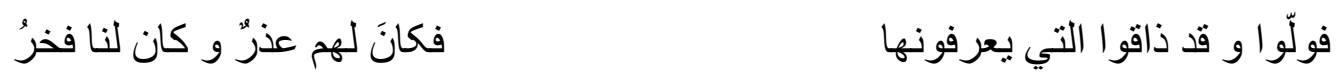

(Therefore, they returned and tasted what they knew; it was an excuse for them and a pride for us)

$$
\begin{aligned}
& \text { وفيتُ له بالؤدِّ فاجتاحه الغدر.... } \\
& \text { و كم من خليلٍ لم أُمَتَّع بعهده } \\
& \text { طلاقَةََ أيدينا و بَشَّرَهُ البِشرُ (همان، 161) } \\
& \text { إذا جاءنا العافي رأي في وجوهنا }
\end{aligned}
$$

(If a needy person comes to us, he would see generosity in our face and our open face would make him happy)

Ibn Moataz prides even in farewell:

$$
\text { ما أَنسَ لا أَنسَ إذ قامت نُوَدِّعنا }
$$

(I will not be calm; the moment of separation and he left us with eyes full of tears)

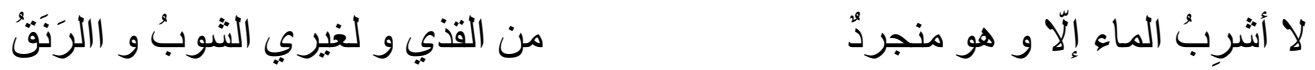

(I drink pure and clear water while others drink muddy and dark water)

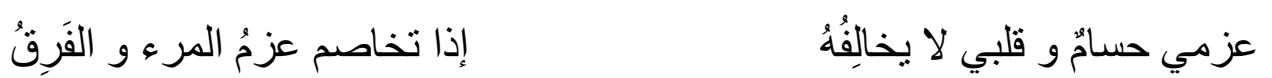

(When the will and fear of a man are conflicted, will is like a sharp sword and my heart would not disagree with it)

Glory is seen throughout Ibn Moataz's set of poets as if it recovers his latent pain of time coercion and we observe such repetition in the poems of many deprived poets like love to nation among poets who have lived out of their country from left to exiled poets like Mahmood Sami ALbardi and Ahmad Shoghi and captives like Abunovas and even in the words of Abdulvahab AL-Bayati who has repeated dialogues on country and city and he was not able to stay in Iraq since he had no home and clear location. 
It seems that Ibn Moataz is eastern Don Quixote $^{1}$ who only a name of his autocratic memories are remained. Perhaps, a type of identity expression is for his superiority and recalling his social distinguished success.

However, one should not ignore that Ibn Moataz's distinguished personality traits cannot be denied. Glory is one of the widest poetical themes in his book and barriers throughout his life to achieve caliphate are not deniable. It should be added that bitter memoirs have been always with him. Glory is used when human is involved by a false pride. The best example is:

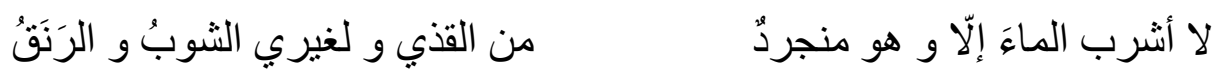

(I drink pure and clear water while others drink muddy and dark water)

If above couplet is put along with two couplets full of lies and blandishment, nothing more than clea water remainsv tha Ibn Moataz drinks:

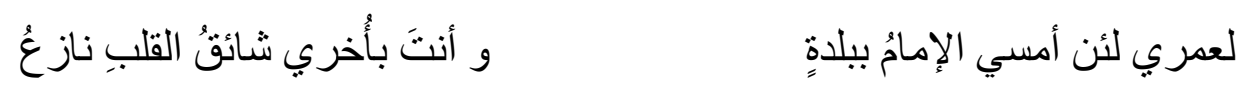

(Oath to my life, if Imam is in one city and you are in another one, you live him)

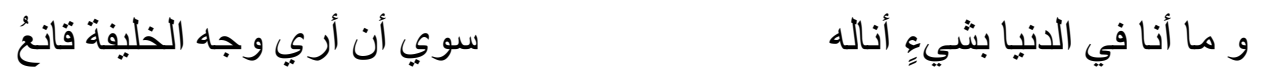

(There is nothing in the world to achieve it and to be convicted except than seen the face of caliph)

It seems that Ibn Moataz has not seen below couplet by Bashar Ibn Bord:

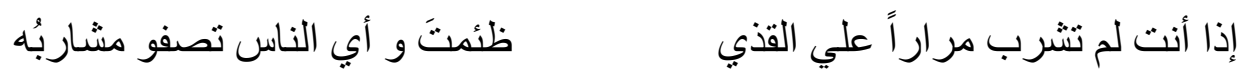

(You will stay thirsty if you do drink muddy water constantly and which human drinks always clean water)

It should be noted that at the end of the same couplet, Ibn Moataz proved drinking muddy water for others which is false claim and shows his false narcissism.

\section{IBN MOATAZ'S POLITICAL PARADOX IN POETRY}

Poets' literal history represents this assumption that the poets of courts or poet commanders have been always influenced by governing policies over courts in their poetries.

In other words, their themes would lead into the benefit of a party or individual. Issues like glory, pray, epics, elegy and intoxication circumvent above target and one can find them hardly in the books of those poems who have achieved the separation of such themes completely.

As a prince, Ibn Moataz should not pray for coins. However, he has no fear to ask by humility from Motazed to transfer from Samira to Baghdad:

$$
\text { لعمري للنُ أمسي الإمامُ ببلدةٍ }
$$

(Oath to my life, if Imam is in one city and you are in another one, you live him)

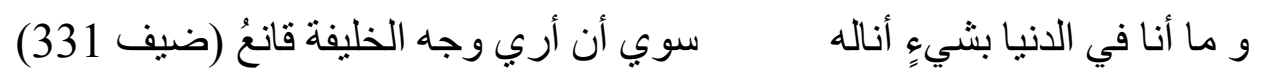

(There is nothing in the world to achieve it and to be convicted except than seen the face of caliph)

\footnotetext{
${ }^{1}$ Dun Quixote is a dispraising revenge which mitigate in the age of author from cavalier order tediousness. Don Quixote was an autocrat who spent his time to read novels on knights and he was so influenced by them that he decided to introduce himself as a great knight and reputed in the world by his conquers. He has big thoughts but he goes to fight against reality since facts are not adapted to him (Moein, vol. 5, 545).
} 
Upon the death of Motazed in 289 (lunar), we observe Ibn Moataz more flatterer than before when he was temporarily imprisoned by a group of Abbasid's great ones to finalize to swear allegiance with Motazed's sone namely Moktafi. Ibn Moataz complains to Ghassem the Son of Suleiman Ibn Vahab as the past minister since Ibn Moataz had severally praised Ghassem and his father during Motazed's caliphate and even has granted gifts to them. When Ibn Moataz prays them he becomes so pleased that:

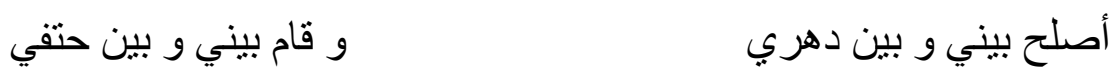

(He compromised between me and bitter time and stood between me and my death)

These are reasons for forgetting the murderers of his father and his social basis as a prince who puts everything aside for survival and he becomes so dispraised in this political strangulation that he has no choice than praising Moktafi and many other commanders (Zeif, 332).

In another political prejudice, he renders his personality paradox so that in his disagreement with Alavians who never stopped contradictory with Abbasids during their history and verifies:

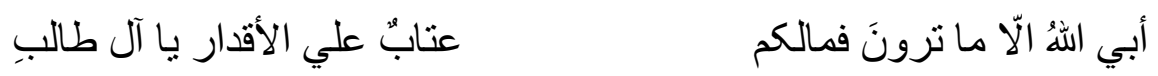

(Divinity does not want. Why you cannot see; Oh Abi Taleb Family! What has happened that you are angry of Divine fate)

As if Abbasid's caliphate is a Divine fate and he believes that Alavians' objection is to protest Divine fate and he is accused of insulting Imam Ali (PBUH), in a contradictory and credulous defense, he versifies:

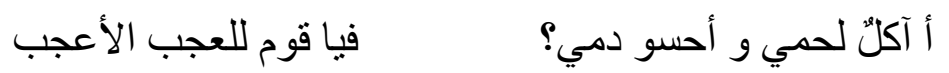

(Do I eat my meat and drink my blood? Oh Tribe! I'm too surprised.)

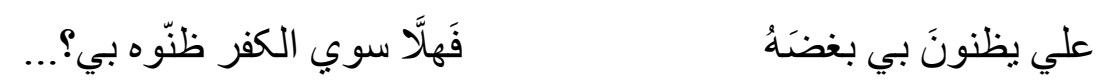

(They believe that I overflow Ali. Why they attribute me blasphemy?)

In defending Abbasids, he believes that Alavians' opposition is to disagree with Divine fate and here he says that Alavians are from his meat and blood and opposing Ali is blasphemy.

Such contradictories in his Book can be found in paramount and it seems that it was to get rid of these contradictories that he accepted caliphate in hurry and worst political crisis. Very soon, he flamed his inner personality by his famous statement: "it is now the time that right is revealed and to shame evil (Islamic Great Encyclopedia, 634).

\section{LYRIC}

Abu Faraj Isfahani says: "although Ibn Moataz's poetry has the softness of court and lyric of clever men and fluency of inventors, it has many modernistic aspects and respect antecedents and has precisely brought many things on kings who were like him and Ibn Moataz found no need to liken him to ignorance big poets (Al-Fil, 232).

Composing "Al-Badie" book by Ibn Moataz is an example of paying attention to antecedents and in this regard, Ibn Moataz says: "my purpose of this book is to aware people that modernists did not surpass antecedents in novelties" (Ibn Moataz, 13).

In lyrics of Ibn Moataz, one cannot see technical lexicons like Abunovas' lyrics in integrating images and mentioned couplets. Also, one cannot find Bashar's enthusiastic lyrics in abusing 
women physically since there is neither Bashar's deprivation in abusing women nor a poet like Abunovas.

Ibn Moataz's lyrics rooted in his autocratic spirit and express the love of a prince who versifies to amuse slave girls and musicians.

$$
\text { و حبيبٍ مني بعيدٍ قريب }
$$

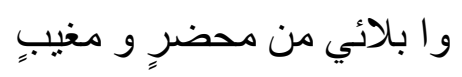

(Alas! Of the attendee and absent and friend far from me while her love is close to me)

$$
\text { لم تَرِدِ ماء وجهه العينُ الاّ }
$$

(Eyes did not return his honor otherwise a protect retained his tears)

And he versifies:

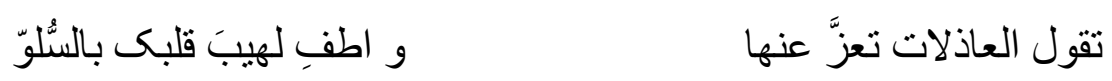

(Blamers say to be patient and extinguish you inner fire by negligence)

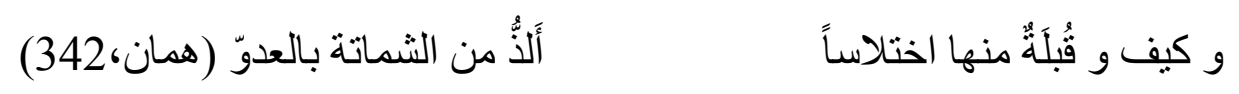

(How is that killing the lover in hidden is sweeter than enemy's bad words)

Or:

$$
\text { إذا اجتني وردةً من خدها فمهُ ت تكوَّ نت تحتها أخري من الخجل (همان،342) }
$$

(If her mouth picks off a red rose form his face, it builds a kind of shy under)

In contrary to Bashar and Abunovas who mention the names of their lovers in their lyrics, in Ibn Moataz's lyrics, one cannot see such names. It is a reason for this claim that Ibn Moataz loved no one.

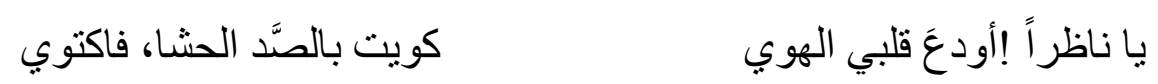

(A watcher who deposited his love in my heart, by prohibiting my inside, you fired me so my inner burnt)

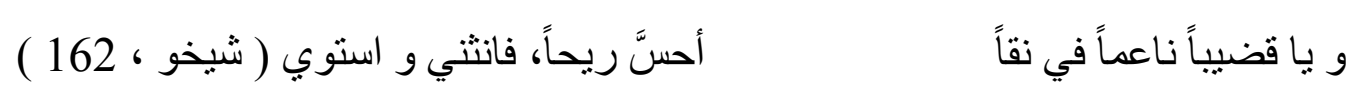

(Oh! Soft cut branch on the sand that felt breeze and turned down and right)

Or:

$$
\text { يا هلالاً يدور في فلى الما-----------مردِ رفقاً بأ عين النظكَّرة (همان ،163) }
$$

(Oh crescent which turns around sky by kind eyes)

And:

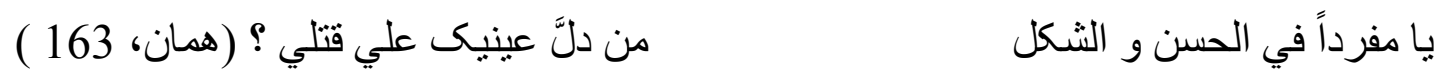

(Oh single in inner and outer beauty! Who conducted your eyes to kill me) 
Although Ibn Moataz was a new emerged poet in Abbasid age, he had lyrics lime many ignorance age poets. He used lyrics at the beginning of elegies like description, pray and intoxication:

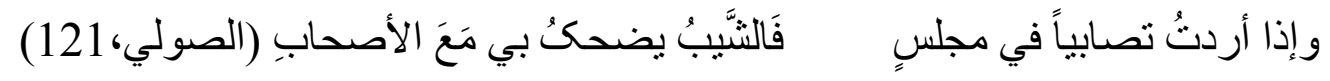

(If want to be in love in a meeting, an old man and my friends would laugh at me)

$$
\text { ولَّي الشبابٌُ و لم يعُد بإيابِ و مَضي بِقَُّةٍ أعينِ الأحبابِ (الصولي ،132) }
$$

(There is no return for youngness and a young man went in love with bright eyes)

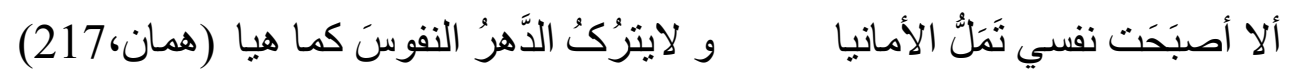

(Be aware that wishes made me sick and as its habit, time does not release me)

\section{HUNTING}

Hunting is the usual amusement of princes especially Abbasid's emirs. Since childhood, Ibn Moataz loved hunting and to the same reason, hunting involve a huge part of his book

Although Ibn Moataz has highly imitated Abunovas, innovation in imagination is what Ibn Moataz is a professional in it. He describes a hunting dog so that it can show all aspects to reader like a camera:

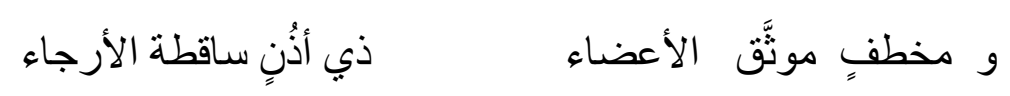

(It is a strong dog with long and hanging ears)

$$
\text { كوردة السوسنة الشهلاء }
$$

(Like red lily blossom of which seems dark blue and nails like of shoemakers' awl)

$$
\text { و مقلةٍ قليلةِ الأقذاء }
$$

(Eye-socket with minimum motes and so clear like water drop)

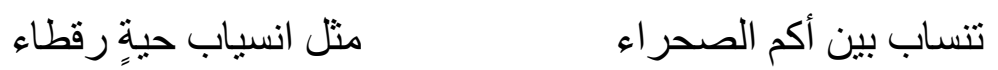

(As comes down desert hill like coming down of a speckled snake)

He has such innovation to describe horse:

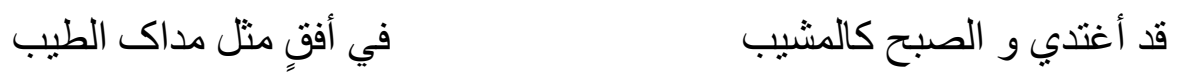

(I go early morning while early morning is like an old man and I go in a horizon like odor stone grinding)

$$
\text { بقار حٍٍ مسوَّم يعبوب }
$$

(I go with a mature and strong and signed horse whose ears like palm leafs)

$$
\text { أو آسةٍ أوفت علي قضيب }
$$

(Or vertical and pillar which right and perfect branch surpasses the horizon of sight)

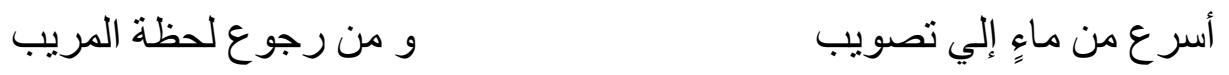

(Faster than water becomes calm and quicker than the moment of returning a suspicious man) 
Ibn Moataz's hunting involves many animals and birds so that he uses all sky and earth to describe them. However, the care of his photographing as a prince who has paramount experiences in hunting is too explicit. Such imaginations can be done only by poet princes like Ibn Moataz. Like a photo over the door, he describes snake:

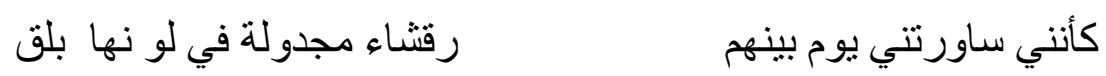

(As if one day I was among them that a colored, black and white snake jumped me)

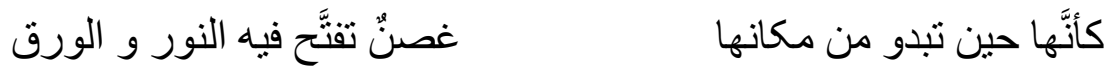

(As if that snake was like a branch grown in light in which a leaf was opening)

$$
\text { كما تعوَّذ بالسَّبابة الغرق (ضيف 346، ) }
$$

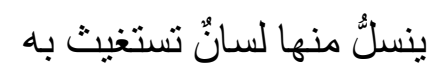

(It brought it tongue out to ask for help like a sank human prays by forefinger)

\section{CONCLUSION}

Abu Al-Abbas Abdullah Ibn Moataz was an Abbasid prince who was king for one night. What distinguishes him from other Abbasid' kings are his writing and poetry power.

He versified for many his contemporary age; however, his most poems were on descriibng wine and nature so that he was considered and "nature describer".

Such reputation and poetry themes in his poems and even writing Al-Badie Book and Fosul Al-Tamasil Fi AL-Sharab and Adabeh root in his social basis so that one can see the impact of this high social status in all parts of his poem book and according to Abu Faraj Isfahani and Abdulghader Jorjani, we can see the impact of his prince in his poems and likening.

On the other hand, events like his father's homicide, his exile and seizing his assets in childhood annoyed him so much that he experienced the concept of animosity and spite. To the same reason, when his cousin Motazed took revenge of his father's murderers, he versified epics for Motazed and revealed his spite in political position against opponents and even in accepting his one-day administration.

Another issue which explains his prince personality is intoxication and hunting. Ibn Moataz's personal experience in palace and drinking wine and hunting are appearing in Bohtari's poems. Ibn Moataz published a book on wine ceremonies in poetry so that he not only experienced exiting the single rhyme but also he provided an actual expression of situations and condition in Abbasid age.

In descriibng hunting, he uses his sight power so that listener sees it like a painting. Only Ibn Moataz is able to express reality of varied wine drinking meetings and visual likening.

Therefore, Ibn Moataz is an autocratic poet in the second Abbasid age that could undoubtedly get us familiar with this class by his poems and works. His difference with other poets like Bohtari, Ebn Rumi and Matnabi is that their glance at society was bottom-up while Ibn Moataz looked at society up-down. It cannot be denied and pointed out by Ebn Rumi.

\section{References:}

[1] Azarshab, Mohamamd Ali (2003), TArikh Al-Adab Al-Arabi Fi Al-Asr Al-Abbasi

[2] Ibn Moataz, Abdullah (2001), Al-Badie, Al-Saghafieh Institute, Beirut

[3] Hussein, Taha (1963), Tajdid Zekri Abu A-Ala, Al-Taba Al-Sadeseh, Encyclopedia, Cairo

[4] .... (2004) Men Hadis Al-Ser va Al-Nasr, Al-Tabae Al-Snaieyh Ashara, encyclopedia, Cairo

[5] Al-Zuzani, Hussein Ibn Ahmed Ibn Al-Hussien (2002), Sharh Moalaght AL-Sabe, Dar Ahya At-Tara Al-Arabi, Beirut 
[6] Sharif, Mohaadm Badi (1989) Divan Ashar Al-Amir Al-Abbas Abdullah Ibn Moataz Be-allah Al-Khalife Al-Abbas, encyclopedia, Cairo

[7] Sheikh, Al-Ab (1998), Al-Majani Al-Hadisa (3), Al-Taba Al-Rabea, Zulgharbi, Qom

[8] Al-Suli, Abubakr Mohamamd Ibn Yahya, (1978), Sheer Ibn Moataz, Al-Ghesm Al-Aval, Darolhoryat

[9] Zeif, Shoghi (1427 lunar) Tarikh Al-Adab Arabi, Zulgharbi, Qom

[10] Abduljalil, H. M. (1994), Arab Literature History, translated by Azarnush, $2^{\text {nd }}$ edition, Amir Kabir Publications, Tehran

[11] Al-Fil, Tofigh (1984), Al-Ghayem AL-Fanyeh Al-Mostahedes (Fi Al-Sher Al-Abbasi Men Bashar Ala Ibn Moataz), Forat Al-Salasel, Kuwait

[12] Marveh, Mohammad Reza (1990), Abdullah Ibn Moataz, Darolkotob Elmiyeh, Beirut

[13] Moosavi Bojnurdi, Kazem (1991), Islamic Great Encyclopedia, vol. 4, Tehran

[14] Nazemina, Reza (2009), contemporary poet and prose texts, Payam Noor Publications, Tehran 